PRACE NAUKOWE UNIWERSYTETU EKONOMICZNEGO WE WROCLAWIU

\title{
Malgorzata Czerny
}

Uniwersytet Ekonomiczny w Poznaniu

e-mail: malgorzata.czerny@ue.poznan.pl

\section{PRÓBA OKREŚLENIA RÓŻNIC KULTUROWYCH I ICH WPŁYWU NA SYSTEM RACHUNKOWOŚCI W WYBRANYCH KRAJACH W ŚWIETLE KONCEPCJI G. HOFSTEDE I S. GRAYA}

\section{AN ATTEMPT TO DEFINE CULTURAL DIFFERENCES AND THEIR IMPACT ON THE ACCOUNTING SYSTEM IN SELECTED COUNTRIES IN THE CONCEPTUAL CONTEXT OF G. HOFSTEDE AND S. GRAY}

DOI: $10.15611 /$ pn.2018.503.09

JEL Classification: M41, M49

Streszczenie: W niniejszym artykule podjęto próbę uchwycenia najważniejszych różnic kulturowych pomiędzy Polską a jej bezpośrednimi sąsiadami - Rosją i Niemcami, w kontekście Hofstede'owskich wymiarów kulturowych, a następnie powiązania ich z kulturalnymi determinantami rachunkowości w świetle koncepcji S. Graya. Zastosowano przy tym metodę studiów literaturowych i wnioskowanie.

Słowa kluczowe: uwarunkowania kulturowe, determinanty rachunkowości, systemy rachunkowości.

Summary: This article attempts to capture the most important cultural differences between Poland and its neighbors - Russia and Germany, in the context of Hofstede's cultural dimensions. Then the author tries to link them with cultural determinants of accounting in the light of the concept of S. Gray. As a research method literature studies and reasoning were applied.

Keywords: cultural dimensions, determinants of accounting, accounting systems.

\section{Wstęp}

Jak słusznie zauważa R. Biadacz, jedną z przyczyn odmiennego kształtowania się zasad rachunkowości w różnych krajach są odrębne uwarunkowania kulturowe. Dzieje się tak dlatego, że kultura, obok takich składowych, jak system prawny i gospodarczy czy poziom rozwoju rynku finansowego, odgrywa istotną rolę w kreowa- 
niu oczekiwań formułowanych wobec rachunkowości funkcjonującej w danym środowisku kulturowym, a jednocześnie wpływa na sposoby realizacji zadań przed nią stawianych [Biadacz 2016]. Kultura stanowi determinantę kształtującą rachunkowość, ponieważ ,system rachunkowości (...) musi odzwierciedlać postulaty kultury, z której wyrósł. (...) Najważniejsze jest, by przed wydaniem opinii na temat rachunkowości jako systemu, zrozumieć tło, w którym ów system się kształtował" [Kamela-Sowińska 2006].

Założenie, że systemy ekonomiczne poszczególnych państw są determinowane przez wpływy kulturowe, sformułował i weryfikował poprzez badania G. Hofstede. Jego prace wywarły niepodważalny wpływ na objaśnienie przyczyn różnic w podejściu do kwantyfikacji w rachunkowości w wymiarze międzynarodowym. Hofstede jako pierwszy sklasyfikował kultury narodowe w kilku przyjętych przez siebie wymiarach, odzwierciedlających pewne normy, wartości i zachowania charakterystyczne dla danej kultury. Według niego istnieje sześć głównych wymiarów narodowych wartości kulturowych [Hofstede, Hofstede 2007, za: Biadacz 2016]:

1) duży/mały dystans władzy, określający poziom przestrzeni emocjonalnej oddzielającej podwładnych od przełożonych. Społeczeństwa o dużym dystansie władzy charakteryzuje hierarchiczny porządek i tym samym znaczna zależność podwładnych od przełożonych, która jest zjawiskiem powszechnie akceptowanym; z kolei społeczeństwa nacechowane małym dystansem władzy odczuwają silną potrzebę wzajemnych konsultacji;

2) kolektywizm/indywidualizm - wymiar opisujący stopień współzależności i niezależności jednostek. Kolektywizm oznacza, że społeczeństwo aprobuje ścisłe normy społeczne, a jednostki oczekują (niejako w zamian) większej pomocy od społeczeństwa. Indywidualizm wiąże się natomiast z preferencją luźnych więzi społecznych, gdzie „każdy ma na uwadze przede wszystkim siebie i swoją najbliższą rodzinę" [Hofstede, Hofstede 2007];

3) „męskość”/,kobiecość” społeczeństwa, odnoszące się do alokacji ról społecznych i płci. W społeczeństwach „męskich” podział ról społecznych dokonuje się według kryterium płci, z tradycyjnymi ich atrybutami. Męskość określa zatem stopień, w jakim dane społeczeństwo akceptuje determinację jednostki do osiagnnięcia postawionych celów i sukcesów materialnych. W społeczeństwach „męskich” oczekuje się od mężczyzn twardości, asertywności, rywalizacji i ukierunkowania na sukcesy materialne, a od kobiet skromności i czułości. Realizacja zadań w społeczeństwie „męskim” jest znacznie istotniejsza aniżeli budowanie relacji. Akceptowane są funkcjonujące powszechnie podwójne standardy (odrębne dla kobiet i mężczyzn) [Aniszewska 2014]. W społeczeństwach „kobiecych” role społeczne obu płci wzajemnie się przenikają, stąd znamienne jest dla nich większe poszanowanie innych wartości aniżeli materialne;

4) silna/słaba skłonność do unikania niepewności, wyznaczająca poziom poczucia zagrożenia $\mathrm{w}$ obliczu nowych, nieznanych sytuacji, co wiąże się z odczuwaną potrzebą przewidywalności, którą można zaspokoić przez wprowadzenie określone- 
go rodzaju prawa i zwyczajów (praktyk). W społeczeństwach silnie unikających niepewności panuje tendencja do utrzymywania sztywnych kodeksów (praktyk) i generalny brak akceptacji zachowań odbiegających od norm, inaczej niż w społeczeństwach o niskim poziomie nasilenia tej cechy;

5) długo-/krótkoterminowa orientacja wiązana m.in. z wytrwałością w stopniowym osiąganiu założonych efektów i oszczędnym gospodarowaniem w przypadku społeczeństw zorientowanych długoterminowo oraz nastawieniem na szybkie rezultaty w przypadku społeczeństw zorientowanych krótkoterminowo;

6) przyzwolenie/restrykcyjność - restrykcyjność społeczeństwa (w odróżnieniu od przyzwolenia) wyraża się w przekonaniu, że czerpanie radości z życia powinno być regulowane normami społecznymi. Restrykcyjność wiąże się z większym poczuciem bezradności, mniejszym znaczeniem czasu wolnego, silniejszą kontrolą, przywiązywaniem większej wagi do zapobiegliwości (zachowawczości), ścisłym określaniem ról płci [Hofstede i in. 2011; Aniszewska 2014].

W niniejszym artykule podjęto próbę uchwycenia najważniejszych różnic kulturowych pomiędzy Polską a jej bezpośrednimi sąsiadami - Rosją i Niemcami, w kontekście Hofstede'owskich wymiarów kulturowych, a następnie powiązania ich z kulturalnymi determinantami rachunkowości w świetle koncepcji S. Graya. Zastosowano przy tym metodę studiów literaturowych i wnioskowanie.

\section{Polska na tle Rosji i Niemiec w świetle wymiarów kulturowych G. Hofstede}

Rysunek 1 prezentuje trzy wybrane kraje znajdujące się na pozór w tym samym, europejskim kręgu kulturowym (Polskę wraz z jej najbliższymi i zarazem największymi sąsiadami - Rosją i Niemcami), pod kątem sześciu wymiarów kulturowych zdefiniowanych przez G. Hofstede. Dwa spośród porównywanych krajów należą etnicznie do grupy narodów słowiańskich, rdzenni mieszkańcy trzeciego z nich to naród germański.

Pod względem dystansu władzy, który najkrócej można scharakteryzować jako stosunek kultury do nierówności między jednostkami, Polaków (z wynikiem 68 wskazującym natężenie danej wartości) można uznać za społeczeństwo hierarchiczne. Oznacza to, że ludzie akceptują hierarchiczny porządek, w którym wszyscy mają swoje miejsce, i nie potrzebują uzasadnienia tego stanu rzeczy. Hierarchia w organizacji jest postrzegana jako odzwierciedlająca naturalne w organizacji społecznej nierówności, centralizacja jest popularna, podwładni oczekują, że przełożony będzie wydawać polecenia, a idealnym szefem jest dobroczynny autokrata. Również Rosjanie, ze swymi 93 punktami, są społeczeństwem bardzo silnie zhierarchizowanym. Jednocześnie jest to kraj niezwykle scentralizowany: $2 / 3$ wszystkich zagranicznych inwestycji trafia do Moskwy, gdzie koncentruje się również 80\% całego potencjału finansowego. Ogromna rozbieżność między ludźmi uplasowanymi wyżej i niżej w hierarchii władzy prowadzi do wzmożonego znaczenia symboli statusu. Zachowanie 


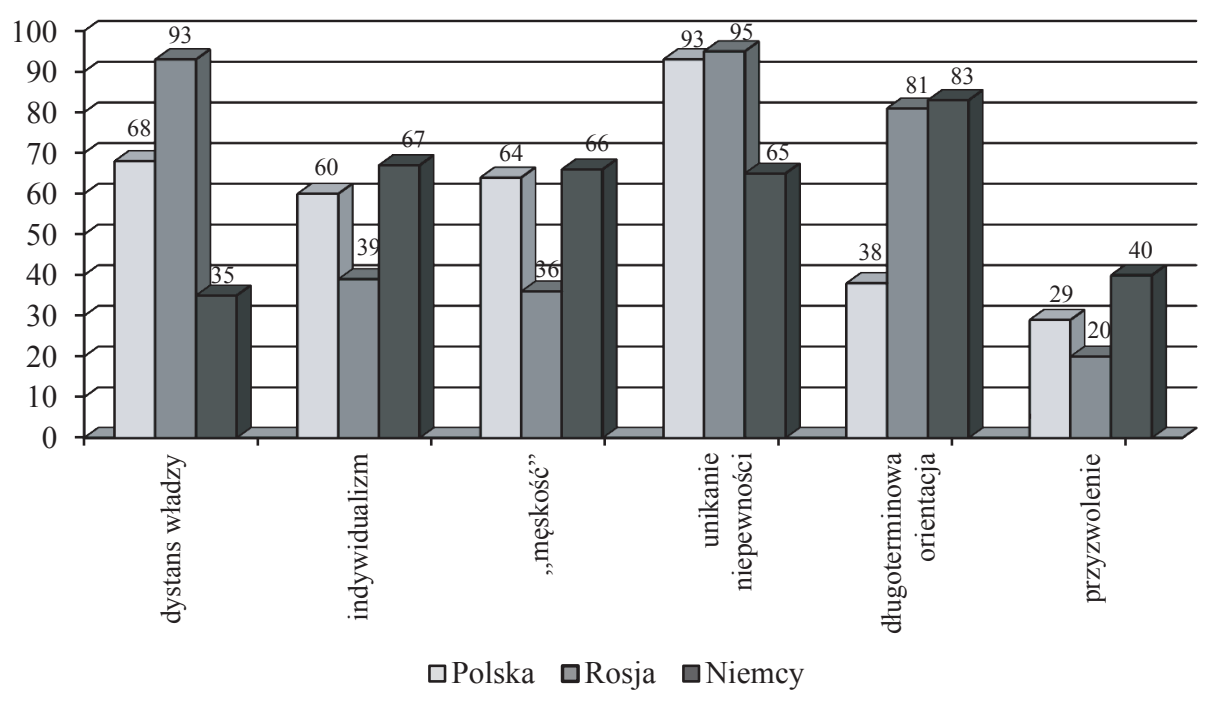

Rys. 1. Wymiary kulturowe - Polska w porównaniu z Rosją i Niemcami

Źródło: opracowanie własne na podstawie [https://geert-hofstede.com/countries.html].

musi odzwierciedlać i reprezentować status jednostki we wszystkich obszarach interakcji biznesowych. Pod tym względem oba kraje słowiańskie wykazują znaczne podobieństwa.

Niemcy są zdecydowanie zdecentralizowane, co jest charakterystyczne dla krajów posiadających silną klasę średnią (wynik 35). W społeczeństwie tym prawo jednostki do współdecydowania musi być uwzględnione przez kierownictwo. Bezpośrednia i uczestnicząca komunikacja jest powszechna, podobnie jak niechęć do kontroli, a przywództwo jest kwestionowane; aby je zachować, nie wystarczy zajmowanie eksponowanego stanowiska, trzeba wykazać się wiedzą fachową.

Pod względem indywidualizmu, rozumianego jako stopień współzależności, jakie społeczeństwo utrzymuje wśród swoich członków, Polska, z wynikiem 60, jawi się jako społeczeństwo indywidualistyczne. W społeczeństwie indywidualistycznym niepowodzenie, podobnie jak przestępstwo, skutkuje winą i utratą poczucia własnej wartości, relacja pracodawców/pracowników jest umową opartą na wzajemnych korzyściach, decyzje o zatrudnieniu i promocji powinny opierać się wyłącznie na zasługach, a zarządzanie to zarządzanie osobami. Należy zwrócić uwagę, że kultura polska w ujęciu Hofstede'owskim stanowi pewną sprzeczność - choć zindywidualizowana, jednocześnie jawi się jako hierarchistyczna. Ta kombinacja tworzy specyficzne „napięcie” kulturowe, co czyni relacje międzyludzkie w wymiarze organizacyjnym i biznesowym delikatnymi i stosunkowo trudnymi, ale jednocześnie intensywnymi i owocnymi, jeśli jednostki potrafią się w nich odnaleźć. 
Podobnie jak polskie, niemieckie społeczeństwo jest indywidualistyczne (wynik 67). Struktura społeczna to najczęściej małe rodziny, koncentrujące się na relacjach między najbliższymi (np. rodzicami a dziećmi), nie zaś dalszymi krewnymi czy powinowatymi. Społeczność tę cechuje silna wiara w ideę autorealizacji. Lojalność opiera się na indywidualnych preferencjach ludzi, a także poczuciu obowiązku i odpowiedzialności. Znajduje to swój wyraz także w niepisanej umowie pomiędzy pracodawcą a pracownikiem. Komunikacja społeczna jest tu jedną z najbardziej bezpośrednich na świecie, a jedną z głównych cnót jest uczciwość i szczerość, przy czym daje się innym uczciwą szansę na wyciagnięcie wniosków $z$ ewentualnie popelnianych błędów.

Niski wynik (39) Rosji wskazuje z kolei na to, iż społeczeństwo to z natury swej jest kolektywistyczne. Dobre relacje z rodzina, przyjaciółmi, a także sąsiadami są tu niezwykle ważne, aby sprostać wyzwaniom życia codziennego. Przekłada się to na kulturę organizacyjną, w której osobiste, poufne związki mają zasadnicze znaczenie w pozyskiwaniu informacji, podejmowaniu decyzji lub udanych negocjacjach.

Biorąc pod uwagę „męskość” analizowanego społeczeństwa, wysoki wynik w tym wymiarze wskazuje, że jego główną siłą napędową jest konkurencja, z ukierunkowaniem na osiągnięcia i sukces, a zwycięzcą zostaje najlepszy w danej dziedzinie. Ten system wartości, wpajany członkom społeczeństwa od najmłodszych lat w domu i szkole, rzutuje na całe życie zawodowe i przesądza o kulturze organizacyjnej. Natomiast niski wynik oznacza, że dominującą wartością w społeczeństwie jest jakość życia, rozumiana jako możliwość samorealizacji i zadowolenie. Społeczeństwo „kobiece” to zatem takie, gdzie za oznakę sukcesu uważa się jakość życia i samo wyróżnienie się z tłumu (bycie najlepszym) niekoniecznie jest czymś godnym podziwu. Podstawową kwestią jest zatem motywacja. Polska osiaga 64 punkty w tym wymiarze, a zatem jest „męskim” społeczeństwem. W tego typu społecznościach ludzie ,żyją, aby pracować”, menedżerowie powinni mieć zdecydowane podejście, kładzie się nacisk na sprawiedliwość, konkurencję i wydajność, a konflikty są rozwiązywane przeważnie poprzez konfrontację.

Stosunkowo niski wynik Rosji, wynoszący 36 punktów, pozwalający zaklasyfikować to społeczeństwo do „żeńskich”, wydaje się zaskakujący w porównaniu z waga, jaką Rosjanie przywiązują do symboli statusu. Należy pamiętać, że ta ostatnia cecha wiąże się przede wszystkim z wysokim poziomem dystansu władzy cechującej rosyjskie społeczeństwo. Rosjanie w miejscu pracy, a także przy pierwszym spotkaniu z nieznajomymi generalnie zaniżają swoje osobiste osiagnięcia czy zdolności. O kulturze człowieka świadczy jego skromność, podobnie ceniony jest powszechnie skromny, niewyróżniający się poziom życia, zwłaszcza jeśli dotyczy osób reprezentujących elitę, szczególnie intelektualną. Pewność siebie, dominujące zachowanie mogą być zaakceptowane, jeśli postawy te prezentuje przełożony, ale zdecydowanie nie spotkają się z uznaniem pośród współpracowników. Dobre, serdeczne wręcz relacje w miejscu pracy mają dla oceny jej jakości decydujące znaczenie. 
Z 66 punktami Niemcy są uważane za „męskie” społeczeństwo. Skuteczność jest wysoce ceniona, podobnie jak wykazywane zdolności i umiejętności, przy czym system szkolny klasyfikuje i „szufladkuje” dzieci już w wieku dziesięciu lat, przypisując je do różnych typów szkół. Niemcy zdecydowanie ,żyją, aby pracować” i ich poczucie własnej wartości jest silnie skorelowane z zadaniami, jakie są im powierzane. Menedżerowie są kompetentni i zdecydowani. Oznaki statusu społecznego są podkreślane przez nabywanie i ostentacyjną demonstrację dóbr materialnych, w szczególności samochodów, zegarków i urządzeń technicznych.

Stopień, w jakim członkowie kultury czują się zagrożeni przez niejednoznaczne lub nieznane sytuacje oraz stworzone przez nie kody zachowań, a nawet instytucje, które mają za zadanie minimalizację lub wyeliminowanie niepewności, znajduje odzwierciedlenie w wynikach dotyczących wymiaru unikania niepewności.

Wszystkie analizowane kraje można zaliczyć do preferujących unikanie niepewności, aczkolwiek w różnym stopniu. Oba społeczeństwa etnicznie słowiańskie charakteryzuje bardzo wysoki wynik w tym wymiarze (Polska osiaga 93, Rosja 95 punktów). Tego typu społeczeństwa formułują zazwyczaj sztywno kodeksy wiary i reguł postępowania, z nieufnością i brakiem akceptacji odnoszą się do niekonwencjonalnych zachowań i nietypowych pomysłów. W kulturach takich istnieje emocjonalna potrzeba regulacji (stąd często nadmierne rozbudowanie biurokracji), czas to pieniądz, ciężka praca, precyzja i punktualność stanowią nie tylko wartość, ale i normę, bezpieczeństwo jest ważnym elementem indywidualnej motywacji. Rosjan, z wynikiem 95, charakteryzuje jako społeczność niezwykle wysokie poczucie zagrożenia niejednoznacznymi sytuacjami (Rosja posiada jeden z najbardziej złożonych systemów biurokratycznych na świecie). Silny imperatyw unikania niepewności zarówno w Polsce, jak i w Rosji powoduje nacisk na bycie bardzo szczegółowo i dobrze przygotowanym, nie tylko ze względu na etos pracy, ale dla własnego dobrego samopoczucia. Szczegółowe planowanie i briefing jest bardzo powszechne. Rosjanie skupiają się dodatkowo na budowaniu dobrych relacji z partnerami biznesowymi, jednak, co należy podkreślić, w obu społeczeństwach zachowanie formalne uznawane jest za przejaw szacunku, bezpośredniość świadczy natomiast o jego bra$\mathrm{ku}$. Jest to szczególnie dobrze widoczne w przypadku Rosjan, którzy podczas spotkań z ludźmi uważanymi za obcych zachowują się niezwykle oficjalnie i wydają się przez to bardzo odlegli, co stoi w rażącej sprzeczności z ich zachowaniem w stosunku do znanych partnerów biznesowych.

Niemcy z wynikiem 65 punktów klasyfikują się również jako społeczeństwo unikania niepewności. Zgodnie z filozoficznym dziedzictwem Kanta, Hegla i Fichtego zdecydowanie preferuje się dedukcyjne, a nie indukcyjne podejście, czy to w myśleniu, prezentowaniu, czy też planowaniu: kontynuacja działań poprzedzona powinna być systematycznym przeglądem i weryfikacją dotychczasowych. Znajduje to również odzwierciedlenie $\mathrm{w}$ niemieckim systemie prawnym. Dopracowanie szczegółów jest niezwykle istotne, aby zyskać pewność, że określony temat lub projekt są dobrze przemyślane. W połączeniu z niskim dystansem władzy, która nie 
pozwala wprost na przerzucenie odpowiedzialności za własne decyzje na przełożonego, powoduje to chęć ograniczenia przez Niemców odczuwanej niepewności, zdecydowanie polegając na wiedzy specjalistycznej.

Wymiar długoterminowej orientacji opisuje, w jaki sposób każde społeczeństwo stara się utrzymywać związki z własną przeszłością w obliczu wyzwań teraźniejszości i przyszłości oraz czy społeczeństwo priorytetowo traktuje te dwa cele egzystencjalne. Społeczeństwa tzw. normatywne, które osiagnęły niski poziom w tym wymiarze, kultywuja tradycje, zmiany społeczne traktując podejrzliwie, cechuje je myślenie schematyczne, według pewnych przyswojonych wzorców, a jednocześnie podejście idealistyczne. Społeczeństwa osiagające wysokie wyniki w tym wymiarze przyjmują bardziej pragmatyczne podejście: zachęcają do oszczędności i starań w zakresie nowoczesnej edukacji, aby przygotować się na przyszłość.

Niski wynik Polski (38) w tym wymiarze oznacza, że Polacy stanowią społeczeństwo bardziej normatywne niż pragmatyczne. Ludzi w takich społeczeństwach cechuje silna skłonność do podejmowania prób „ustalenia absolutnej prawdy”. Wyrażają wielki szacunek dla tradycji, mają stosunkowo niską skłonność do oszczędzania na przyszłość i skupienia się na osiagnięciu szybkich wyników.

Co ciekawe, z bardzo wysokim wynikiem 81 punktów Rosja jest zdecydowanie krajem o pragmatycznym nastawieniu. Pod tym względem niewiele odbiega od Niemiec (z wynikiem 83 punktów). W społeczeństwach o orientacji pragmatycznej ludzie wierza, że prawda zależy w dużym stopniu od sytuacji, kontekstu i czasu (co w społeczeństwie normatywnym, np. polskim, potraktowane byłoby jako pejoratywny relatywizm czy wręcz ,daltonizm” moralny). Wykazują umiejętność łatwego dostosowywania tradycji do zmieniających się warunków, silną skłonność do oszczędzania i inwestowania, wytrwałość w osiaganiu wyników.

Jednym z wyzwań, które stoją przed ludzkością, teraz i w przeszłości, jest stopień socjalizacji obywateli. Wymiar przyzwolenia (lub restrykcyjności) określa się zatem jako stopień, w jakim ludzie starają się kontrolować swoje pragnienia i impulsy zgodnie ze sposobem ich wychowywania. Stosunkowo słaba kontrola przekłada się na „przyzwolenie”, gdy jest relatywnie silna - na restrykcyjność.

Z niską liczbą punktów (29 dla Polski, 20 dla Rosji) obie analizowane kultury można sklasyfikować jako zdecydowanie restrykcyjne. Społeczeństwa tego typu, nazywane też ,powściągliwymi”, wykazują tendencję do cynizmu i pesymizmu. Nie przywiązują dużej wagi do czasu wolnego i kontrolują zaspokajanie swoich pragnień. Jednostki mają poczucie, że ich działania są (i być powinny) ograniczane przez normy społeczne (dobro społeczne jest dobrem, jeśli nie nadrzędnym, to w każdym razie „wyższym” aniżeli dobro jednostki). Postawy hedonistyczne, podobnie jak zdecydowane nastawienie na realizację własnych potrzeb, są postrzegane jako egoizm.

Podobnie dość niski wynik (40) w tym wymiarze wskazuje, że niemiecka kultura należy do restrykcyjnych, choć nie w takim stopniu jak obie porównywane z nią kultury słowiańskie. 
Najważniejsze różnice kulturowe w modelu G. Hofstede między Polską a Niemcami koncentrują się na orientacji długoterminowej, dystansie władzy i unikaniu niepewności. Polski dystans władzy stoi na przeszkodzie wyraźnej komunikacji i konfrontacji z przełożonymi. Unikanie niepewności przekłada się na unikanie ryzykownej sytuacji przeciwstawiania się szefowi. W deklaracjach Polacy cenią asertywność bardziej niż Niemcy (jest to cecha kultur „męskich”, do których oba narody należą). Niemniej jednak, jeśli chodzi o praktykę, kultura polska jest mniej asertywna niż niemiecka (co znajduje potwierdzenie w różnicy punktowej wymiaru „męskości”, przedstawionej na rys. 1). To ogranicza Polakom swobodne przekazywanie przełożonym własnych opinii, szczególnie tych o kluczowym znaczeniu. Ponadto, ponieważ asertywność jest ważna zgodnie z zadeklarowanymi wartościami w polskim społeczeństwie, polscy menedżerowie nie są zazwyczaj świadomi swoich problemów z praktyczną asertywnością [Nowak 2016]. Polski kolektywizm grupowy jest silniejszy od niemieckiego (pod względem deklaracji wartości i praktyk). Oznacza to, że grupa polskich pracowników okaże sobie nawzajem więcej solidarności, niż miałoby to miejsce pomiędzy pracownikami polskimi i niemieckimi, w szczególności zaś niemieckimi przełożonymi. Istnieje również duża luka między polskimi i niemieckimi praktykami „przyszłej orientacji”. Oznacza to, że polscy menedżerowie nie zrozumieją ani nie zgodzą się z planami niemieckich menedżerów [Nowak 2016].

Co do istotnych różnic kulturowych między Polską a Rosją, wynikają one zwłaszcza z kontrastów w dystansie władzy, indywidualizmie i „męskości”. Kulturę rosyjską cechuje znacznie większy dystans władzy, co wyjaśnia swoistą bierność rosyjskich pracowników, którzy oczekują od swoich przełożonych szczegółowych informacji i poleceń. Polak nie uzyska od rosyjskiego podwładnego opinii lub sugestii. Polska kultura ma wyższy wskaźnik indywidualizmu, ponadto jest bardziej „męska”. Oznacza to, że priorytetem polskiego menedżera jest uzyskanie efektu ilościowego i wyników finansowych oraz zwiększenie konkurencyjności firmy, że koncentruje się na wykonywaniu pracy i spełnianiu standardów (ukierunkowanie na wyniki). W Rosji orientacja humanitarna jest wyższa niż w Polsce. Rosyjscy pracownicy dbają bardziej o relacje i atmosferę ich pracy, nie będą zatem tak zorientowani na pracę, jak oczekują polscy menedżerowie. Skupiają się raczej na kontaktach ze współpracownikami, wyrażają życzliwość i manifestują grzeczność wobec nich. Co więcej, Rosjanie charakteryzują się wyższym poziomem kolektywizmu grupowego, co ponownie przekłada się na to, że silniej dbają o stosunki międzyludzkie z ich współpracownikami jako członkami grupy niż Polacy [Nowak 2016].

\section{Cechy kultury narodowej według G. Hofstede a ich wpływ na rachunkowość w świetle koncepcji S. Graya}

Cechy (wymiary) kultury narodowej zidentyfikowane przez Hofstede rzutują także na rachunkowość. Uzasadnić to można w następujący sposób: jest logiczne, iż w krajach o małym dystansie władzy ( $w$ tym wypadku np. w Niemczech) normy 
rachunkowości przyjmują przeważnie postać profesjonalnych standardów, wychodzących naprzeciw potrzebom praktyki. Duży dystans władzy (jak w Polsce i Rosji) przekłada się natomiast na jednolitość zasad i procedur rachunkowości [Kabalski 2009] oraz „postrzeganie danych liczbowych jako wiarygodnego narzędzia służącego zaprezentowaniu pożądanego wizerunku" [Hofstede, Hofstede 2007; Silska-Gembka 2013]. Społeczeństwa „męskie” (Polska, Niemcy) mają tendencję, by przywiązywać większą wagę do czysto finansowych wyników, w przeciwieństwie do „kobiecych” (Rosja), a te o orientacji krótkoterminowej (jak Polska) zainteresowane są ich szybszym osiagnięciem od zorientowanych długoterminowo (Rosja, Niemcy) [Silska-Gembka 2013]. Ponadto „w kulturach indywidualistycznych wszelkie dane rachunkowe są traktowane $\mathrm{z}$ większym namaszczeniem i wydają się bardziej niezastapione niż w kulturach kolektywistycznych" [Hofstede, Hofstede 2007]. Co więcej, praktyki rachunkowości mogą być z powodzeniem uznane za swoiste „rytuały zmniejszające niepewność” [Hofstede, Hofstede 2007]. To pozwala na stwierdzenie, że stopień unikania niepewności cechujący poszczególne społeczeństwa (kraje) będzie oddziaływać na przyjęte tam sposoby prowadzenia rachunkowości [Silska-Gembka 2013; Akman 2011].

Bez wątpienia przełom w badaniach nad uwarunkowaniami kulturowymi rachunkowości stanowiła praca S. Graya [1988]. Wyodrębnione przez G. Hofstede wymiary kulturowe stały się dla Graya podstawą do próby ich połączenia z praktyką rachunkowości (regulacjami, zakresem ujawnień itp.) celem zdefiniowania zbioru cech kulturowych odnoszących się do rachunkowości. Ostatecznie S. Gray sformułował cztery z takich cech, w sposobie ich prezentacji nawiązując do „rozbieżności” sklasyfikowanych przez Hofstede:

1) profesjonalizm/kontrola prawna - zawodowa samoregulacja jako alternatywa dla konieczności podporządkowania się określonym przepisom, kontroli ustawowej;

2) ujednolicenie/elastyczność - preferencja dla ujednoliconych rozwiązań lub elastyczność ich zastosowania w zależności od zmieniających się okoliczności, warunków działania;

3) konserwatyzm/optymizm - ostrożne podejście do pomiaru wartości (w warunkach niepewności), przeciwstawione agresywnemu, optymistycznemu stosowaniu metod wyceny;

4) poufność/jawność - dyskrecja i ograniczenia ujawnień, przy czym alternatywnym podejściem jest przejrzystość, szeroki zakres ujawnień informacji w sprawozdawczości finansowej.

Podejście społeczeństwa do zagadnień profesjonalizmu i elastyczności zdaniem S. Graya przesądza o kształcie określonych instytucji oraz regulacji systemu rachunkowości [za: Silska-Gembka 2013, s. 5]. Konserwatyzm zaś, według Graya, to najstarszy i zarazem najbardziej dominujący wymiar, wraz z poufnością najmocniej wpływający na wycenę i poziom ujawnień w sprawozdaniu finansowym [Gray 1988]. 
Ponieważ cechy subkultury rachunkowości S. Graya pozostają w ścisłej relacji z wymiarami wartości G. Hofstede, pozwalającymi dzięki kwantyfikacji określić pozycję danej kultury wobec innych, można przyjąć, że:

- w społeczeństwach, które cechuje wysoka skłonność do unikania niepewności oraz orientacja długoterminowa, a jednocześnie niski poziom indywidualizmu oraz „męskości”, można się spodziewać ostrożnego podejścia do pomiaru wartości, co przełoży się na wysoki poziom konserwatyzmu w rachunkowości, przy czym spośród wymienionych wymiarów kulturowych to unikanie niepewności i orientacja dhugoterminowa będą w tym wypadku decydujące [Gray 1988; Radebaugh, Gray 2002];

- wysoki poziom unikania niepewności oraz dystansu władzy, orientacja długoterminowa przy niskim poziomie indywidualizmu i „męskości” będzie prawdopodobnie przesądzać o wyższej krajowej randze poufności [Gray 1988; Radebaugh, Gray 2002].

\section{Zakończenie}

Konserwatyzm jako najistotniejszy wymiar kulturowy w klasyfikacji S. Graya wyraźnie różnicuje krajowe modele rachunkowości w zależności od części świata, poczynając od mocno konserwatywnych (kraje arabskie i romańskie, niektóre spośród krajów azjatyckich - jak Japonia), poprzez niższy jego poziom w krajach germańskich (Niemcy, Szwajcaria, Austria), aż po optymizm cechujący rachunkowość anglosaską i skandynawską [Silska-Gembka 3013]. Analogiczne różnice zauważa się w wykazywanej tendencji do poufności (dyskrecja, ograniczone ujawnianie informacji sprawozdawczych) [Silska-Gembka 3013]. Te dwie cechy (konserwatyzm, poziom poufności) są też najczęściej wykorzystywane przy prowadzeniu badań z zakresu porównywalności międzykulturowej sprawozdań finansowych [por. Doupnik, Riccio 2006].

Biorąc pod uwagę pozostałe wymiary kulturowe zidentyfikowane przez S. Graya, czyli podejście do elastyczności rozwiązań w rachunkowości i preferencję dla kontroli prawnej, na równi z omówionymi powyżej konserwatyzmem i skłonnością do ujawnień lub jej brakiem, można następująco scharakteryzować kraje analizowane w artykule:

- społeczeństwo rosyjskie, jako cechujące się wysokimi wskaźnikami dystansu władzy oraz unikania niepewności, restrykcyjnością, „kobiecością” i kolektywizmem, zorientowane długoterminowo, ma wszelkie dane, by wykazywać silną skłonność do konserwatyzmu i dyskrecji ujawnień, będzie też raczej preferować kontrolę prawną aniżeli zawodową samoregulację, podobnie jak skłonność raczej do ujednoliconych rozwiązań; w ten właśnie sposób kształtuje swą subkulturę rachunkowości;

- subkultura rachunkowości w społeczeństwie niemieckim, które cechuje relatywnie niewielki dystans władzy, „męskość” i indywidualizm oraz unikanie niepew- 
ności, przy jednoczesnej stosunkowej restrykcyjności i wyraźnej orientacji długoterminowej, może być scharakteryzowana jako konserwatywna, ze skłonnością do zachowania poufności, skłaniająca się raczej ku profesjonalizmowi, lecz doceniająca jednocześnie rolę kontroli ustawowej, podobnie ambiwaletny stosunek wykazuje w odniesieniu do ujednolicenia a elastyczności;

- społeczeństwo polskie plasuje się jak gdyby „pomiędzy” dwoma pozostałymi; jako cechujące się wysokim wskaźnikiem dystansu władzy oraz unikaniem niepewności, restrykcyjnością, „męskością”, a zarazem indywidualizmem i raczej krótkoterminową orientacją, ma stosunkowo niewielkie predyspozycje do konserwatyzmu (wykazuje zaledwie jedną cechę za nim przemawiająca, wysoki poziom niechęci do podejmowania ryzyka); wyraża się to w polityce ukierunkowanej na rentowność i bieżące wykazywanie jak największego zysku [Kabalski 2009]; mimo cechującego społeczeństwo wysokiego poziomu unikania ryzyka stosowanie np. wyceny w wartości godziwej nie napotyka na szczególny opór. Jednocześnie ranga krajowa poufności jest dość wysoka (o czym obok niechęci do ryzyka przesądza hierarchizacja społeczeństwa - duży dystans władzy). Polska subkultura rachunkowości, podobnie jak niemiecka, wykazuje ambiwalencję w stosunku do roli kontroli prawnej a znaczenia profesjonalizmu (z jednej strony mentalność społeczeństwa hierarchicznego, restrykcyjnego, nieskłonnego do podejmowania ryzyka skłania do uznania konieczności podporządkowania się przepisom, z drugiej zaś indywidualizm i orientacja krótkoterminowa sprzyjają uznaniu dla samoregulacji). Podobnie dzieje się w przypadku elastyczności rozwiązań a ich ujednolicenia.

\section{Literatura}

Akman N.H., 2011, The Effect of IFRS Adoption on Financial Disclosure: Does Culture Still Play a Role?, American International Journal of Contemporary Research, vol. 1, nr 1, s. 6-17.

Aniszewska G., 2014, Kultura organizacyjna przedsiębiorstw produkcyjnych w Polsce - hipotezy badawcze, Prace Naukowe Uniwersytetu Ekonomicznego we Wrocławiu, nr 366. Zarządzanie strategiczne w teorii i praktyce, Wydawnictwo Uniwersytetu Ekonomicznego we Wrocławiu, Wrocław.

Biadacz R., 2016, Czynniki warunkujące rozwój rachunkowości w XXI wieku - wybrane problemy, Finanse, Rynki Finansowe, Ubezpieczenia nr 2(80), cz. 2, s. 21-29.

Doupnik T.S., Riccio E.L., 2006, The influence of conservatism and secrecy on the interpretation of verbal probability expressions in the Anglo and Latin cultural areas, The International Journal of Accounting, vol. 41, s. 237-261.

Gray J., 1988, Towards a Theory of Cultural Influence on the Development of Accounting System Internationally, Abacus, nr 24, s. 1-15.

Hofstede G., Hofstede G.J., 2007, Kultury i organizacje. Zaprogramowanie umystu, PWE, Warszawa.

Hofstede G., Hofstede G.J., Minkov M., 2011, Kultury i organizacje. Zaprogramowanie umyshu, PWE, Warszawa.

https://geert-hofstede.com/countries.html (dostęp: 6.04.207).

Kabalski P., 2009, Polityka rachunkowości w spółce stosujacej MSSF, SKwP, Warszawa. 
Kamela-Sowińska A., 2006, Rachunkowość od antropologii do międzynarodowych standardów, [w:] Kiziukiewicz T. (red.), Rachunkowość w zarzadzaniu jednostkami gospodarczymi, Wydawnictwo Uniwersytetu Szczecińskiego, Szczecin.

Nowak M., 2016, Cultural determinants of accounting, performance management and costs problems. $A$ view from the Polish perspective using G. Hofstede's and GLOBE culture dimensions, Prace Naukowe Uniwersytetu Ekonomicznego we Wrocławiu, nr 441. Global Challenges of Management Control and Reporting, Wydawnictwo Uniwersytetu Ekonomicznego we Wrocławiu, Wrocław. Radebaugh L.H., Gray S.J., 2002, International Accounting and Multinational Enterprises, (5th ed).

Silska-Gembka S., 2013, Kulturowe uwarunkowania kwantyfikacji w rachunkowości, https://www.researchgate.net/publication/310844114 (dostęp: 7.04.2017). 